\title{
FELSŐ VÉGTAGI BÉNULTAK SZÁMÁRA HASZNÁLHATÓ MECHA- NIKUS KORMÁNYSZERKEZET KONCEPCIONÁLIS TERVEZÉSE
}

\author{
Kántor Kristóf \\ BSc. géptervezö hallgató, Miskolci Egyetem, Gép-és Terméktervezési Intézet \\ 3515 Miskolc, Miskolc-Egyetemváros, e-mail: kksalieri@gmail.com \\ Rézsó Ferencné \\ mesteroktató, Miskolci Egyetem, Gép-és Terméktervezési Intézet \\ 3515 Miskolc, Miskolc-Egyetemváros, e-mail: machbk@uni-miskolc.hu \\ Kamondi László \\ cimzetes egyetemi tanár, Miskolci Egyetem, Gép-és Terméktervezési Intézet \\ 3515 Miskolc, Miskolc-Egyetemváros, e-mail:machkl@uni-miskolc.hu
}

\begin{abstract}
Absztrakt
Nap mint nap találkozhatunk olyan személyekkel, akik tolószékesek, kis növésüek, vagy más olyan mozgás problémával rendelkeznek, melyek első gondolatra nem férnek össze az önálló jármüvezetéssel, mégis jogositvánnyal és autóval rendelkeznek. Magyarországon sajnos a felsö végtagi bénultak nincsenek ilyen szerencsés helyzetben. Feladatunk egy számukra használható eszköz koncepcionális tervezése. Célunk egy olyan megoldás létrehozása, amely univerzális, könnyen beépithetö, valamint kiés beszerelhetö, igy a családoknak nem szükséges egy második autó vásárlása.
\end{abstract}

Kulcsszavak: koncepcionális tervezés, kormányzószerkezet, jármü átalakitás

\begin{abstract}
Day after day we can meet people who are disabled, midgets or have other motion problems which keep out them from the self-dependent driving. Still they have driving licence and car. Unfortunatelly in Hungary for those who have upper limb paralyzation aren't as lucky as who are mentioned before. My task was to design a device that can be used by them. Our mission to make a solution which is universal, easily can install and detachable so it isn't nessesary to buy a second car for the families.
\end{abstract}

Keywords: conceptual design, steering device, vechicle modification

\section{Bevezetés}

Az emberek évezredek óta próbálják hiányosságaikat pótolni. Ezek a hiányosságok lényegesen roszszabb életminőséget jelentenek más élölényekkel, vagy saját embertársaikkal szemben. Utóbbi esetben a pótlások két funkciót töltenek be: az adott személy megjelenését javítják, emellett müködőképesek is lehetnek, mellyel fontos feladatot látnak el a mindennapok során. A müvégtagok fejlödésében a két funkció nem mindig volt jelen egyszerre. Először csak olyan protéziseket tudtak készíteni, melyekkel csak a hiány látványát pótolták, majd később a pótolt végtag funkcióját is képesek voltak ellátni. [1]

Habár az autózás széleskörü elterjedésétől időben távol állt, mégis fontos mérföldkő volt az amerikai polgárháború (1861-1865). Ebben a konfliktusban veszítette Amerika a legtöbb katonáját. A nagy veszteség mellett becslések szerint 60.000 amputációt végeztek el. [2] Az amputált veteránok segítésé- 
re az ország az orvosi segédeszközök piaca felé nyitott. Az első világháborút követően érdekszervezet jött létre a mozgáskorlátozott veteránok számára, valamint törvényi elöírás született arról, hogy milyen kedvezményes jogok illetik meg őket. Ezek a jogok a második világháborút és az azutáni konfliktusokat követően folyamatosan bővültek. [3]

A második világháború során a személyautó gyártás szinte megszünt az Államok szerte. A viszszaesést követően az 1950-es éveket robbanásszerü termelés jellemezte. Ezáltal a fogyasztók köre is bővült. 1958-ban szabadalmaztatta David Kope Jármükormányzó eszközét (1. ábra). A szerkezet lehetővé tette, hogy olyan személyek is önállóan utazhassanak személyautóval, akik karjukat elveszítették, vagy bénulás miatt nem tudták használni. [5] Még ebben az évben a veteránok jogai közé került, hogy az autó speciális felszerelését biztosítani kell számukra. [4] Így feltehetően ők lehettek az elsők, akik élvezhették Kope munkájának gyümölcsét. Az átfogó vezetés tréningre azonban csaknem két évtizedet még várniuk kellett az amerikai mozgáskorlátozottaknak.

\section{Az eszköz használata}

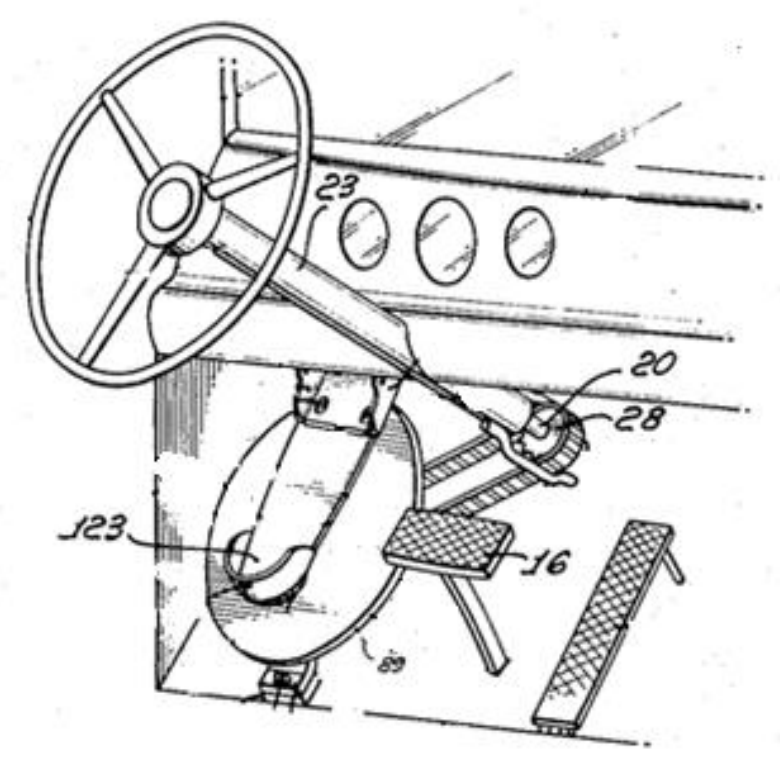

1. ábra. David Kope szabadalma

Az előzőekben említett 1958-as megoldás (1. ábra) a mai napig megtalálható a piacon. Ezt a szabadalom keletkezésekor az amputáltak és a felső végtagi bénultak számára ajánlotta Kope. Azonban a ma elérhető fejlett végtagprotézisek mellett használata inkább csak a bénulások esetén válik szükségessé.

Az eszköz egy forgótárcsából (89). a tárcsára rögzített kengyelből (123), két lánckerékből (67 és 28) és az ezeket összekötő láncból áll. A tárcsához kapcsolódik egy csapágyazott tengely, ennek a végén van rögzítve a (67)-es számú lánckerék. A tárcsa elforgatásával pontosan ugyanazt a mozgást lehet megtenni, mint a kormánykerékkel. A soför a lábfejét egy speciális kengyelbe helyezi vezetés közben. A kengyel a cipő talpboltozati részénél egy forgócsappal van rögzítve a forgótárcsához. A kengyel alátámasztás nélkül. alaphelyzetben a tárcsával hegyes szöget bezárva áll. A kengyel sarok részét lenyomva, az alján kialakított sarokkal két ponton stabilan megtámasztható. Ez akkor szükséges, 
ha nagy forgalomban kell vezetni, vagy precíz kormánymozdulatokat kell végezni. Ekkor ugyanis sokkal finomabb mozgást lehet elérni. A kengyel sarkát alaphelyzetbe állítva, a kengyelt óramutató járásával ellentétesen elforgatva lehetősége nyílik a soförnek a fékpedál (16) lenyomására. Erre például lejtőn történő elinduláskor lehet szükség. Ez a funkció a mai modern automata autóknál már feleslegessé vált. A kormányrúdra (20) a (28)-as számú lánckereket valamilyen kötőeljárással rögzítik. Ehhez a kormányoszlopból (23) ki kell vágni egy részt.

\section{A piac helyzete}

A KSH adatai szerint 2011-ben Magyarország teljes lakosságának 0,014\%-át tették ki a 20 és 69 éves kor közötti mozgássérültek. [6] Az Egyesült Államokat nézve 2016-ban 10,6\%-a volt a teljes népességnek a 18 és 64 év közötti korlátozott ember, akik közül 5,1\% volt azok száma, akik mozgássérültek. [7] Világszintủ statisztika azonban nem áll rendelkezésre arról, hogy hány ember élhet olyan felső végtagi bénulással, mely esetén ezen a szerkezetek használatára szorul. Az interneten számos céget találni, akik megtervezik és beszerelik az adott autóba az eszközt. Arról pedig, hogy a gyakorlatban hogyan müködik, jó leírást adhat Tom Willis, aki 1977-től több mint 500.000 mérföldet vezetett lábbal. [8] Mind az USA-ban, mind Európában és a világ fejlett részein majdnem mindenhol elérhetőek ezek az átalakítások. A kivételek közé tartozik Magyarország is. Habár jogi oldalról a vezetői- és forgalmi engedély kiadható, ilyen átalakítást még nem végeztek el.

\section{A munka és a végeredmény}

A szabadalom és piackutatás után, az ott gyüjtött információk összegzése és értelmezése volt a feladat. Az összegzett adatokat megvizsgálva létrehoztam egy általános leírást. Ez tartalmazza az egyes alkotóelemek előforduló változatait és tulajdonságait. Ebből a leírásból elkészítettem egy általános szerkezet funkcióábráját, melyet négy főelemre osztottam: mozgásindítás, mozgásátadás, kormánymü és kerék. Utóbbi kettő a jármü eredeti, már meglévő része.

A piacon fellelhető mechanikus megoldások a mozgás indításra alapvetően két megoldást adnak: a lábtárcsára rögzített cipő és a kengyel. Habár a rögzített cipő használata is megoldható, én mégis inkább a kengyelt választottam. A sofőr így bármilyen cipőben vezethet, nem kell könnyen levehetőnek lennie (pl. papucs, amit több országban vezetés során tilos viselni).

A mozgásátadás tekintetében szintén két alapvető típus létezik: rugalmas hajtás, vagy alakzáró hajtás. Utóbbi esetén a forgatónyomatékot egy kardáncsuklós tengelyrendszer segítségével lehet közölni. A legelterjedtebb és legegyszerübb megoldás a David Kope szabadalma. Azonban a mai modern kormányoszlopok esetében előfordulhat, hogy átalakítás nélkül, vagy akár azzal sem lehet kivitelezni, hogy a lánchajtás egytengelyü legyen.

Az elemzések és a funkciók megállapítása után létrehoztam egy követelményjegyzéket. A jegyzékben szereplö tételek közül kiválasztottam azokat, amelyek a legfontosabbak és a későbbiekben az értékelés során kritériumként fognak szolgálni. Az értékelő kritériumok az alábbiak voltak: pontos mozgásátadás, biztonságos üzemeltetés, kényelmes használat, költséghatékonyság, alacsony karbantartási igény, univerzalitás, visszaalakíthatóság. A sofőr és a közlekedés többi résztvevőjének a biztonsága mellett a legfontosabb célom egy olyan végeredmény megtalálása volt, amely minden automata sebességváltóval rendelkező autóba beilleszthető, az áthajtást pedig reverzibilisen lehet rögzíteni a kormányrúdra. 
Az értékelő kritériumok egymáshoz viszonyított fontosságát ezután mátrix módszerrel állapítottam meg. A mátrixot ezután soronként összesítettem, így egy oszlopvektort kaptam. Az oszlopvektor elemeit viszonyszámmá alakítottam, így ezeket az értékeket súlyozó faktorként használtam a továbbiakban. Az értékelés folyamán 8 embert kértem meg, hogy a megoldásváltozatokat az adott kritériumok alapján pontozzák. A pontozás alapját a használati értékanalízis $0 \div 10$-ig terjedő skálája biztosította. A különböző emberek által adott pontszámokat kritériumonként átlagoltam, majd azokkal a pontszámokkal végeztem el az értékelést. A legtöbb pontszámot az 1958-as szabadalom kapta. A második és harmadik helyezett összpontszáma között kétszázados eltérés mutatkozott. Mivel a módszer nyertes megoldása nem minden autóban alkalmazható, a második megoldás pedig az elsődleges elemzés alapján drágának bizonyult, így a választott változat a harmadik helyezett lett.(2. ábra)

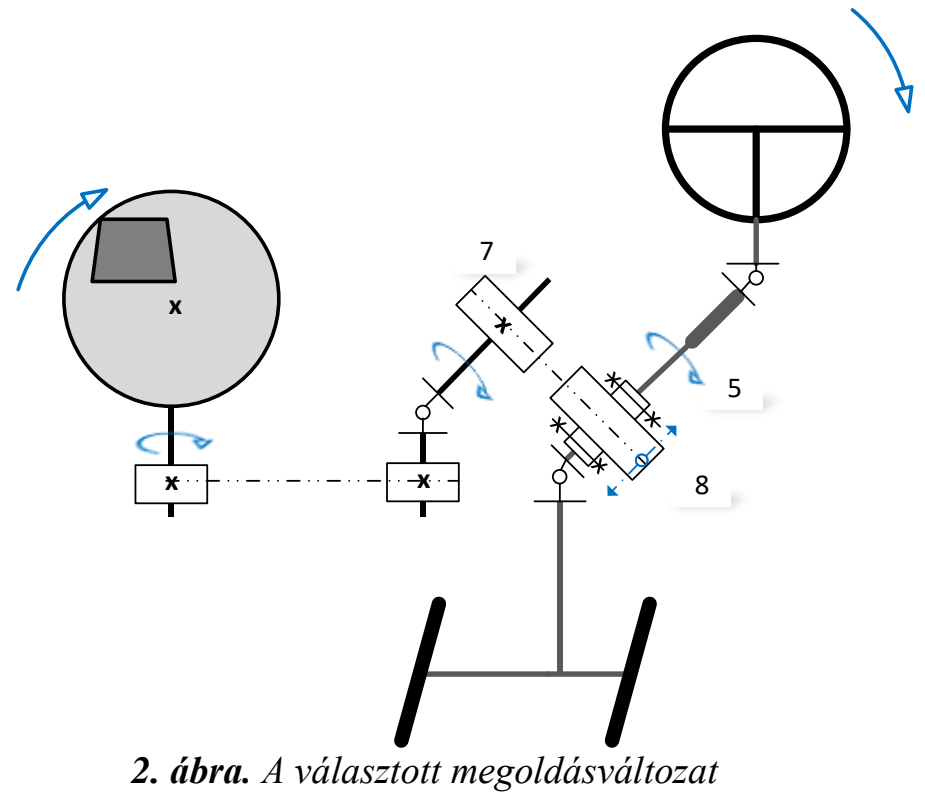

A csuklós előtéttengely (7) segítségével a kormányrúd (5) szögétől függetlenül biztosítani lehet a hajtás egytengelyüségét. Ezenkívül a kormányrúdon könnyebben elhelyezhető a hajtás gépeleme (8). Amennyiben a 8-as számú elem agyas kivitelben készül úgy a kormányoszlop kiszerelésére nincs szükség. Mindkettő rugalmas hajtásnál követelmény a pontos mozgásátadás, így ezeket lánccal, vagy keresztbordás szíjjal lehet kivitelezni. [11]

\section{5. Összefoglalás}

A röviden bemutatott tervezési folyamat során meglepő volt látni azt, hogy milyen a piac helyzete világszerte. Hiába ezek az emberek a teljes társadalom töredékét tehetik ki, mégis a XXI. században a mobilitás alapkövetelmény lehet sok esetben. Az értékelő eljárás igazolta, hogy a bemutatott szabadalom jogosan a legelterjedtebb megoldás a piacon. Azonban úgy gondolom az általam választott megoldás több funkciót tud nyújtani a vásárlóknak. A tényleges tervezés előtt még sok tennivaló van, mechanikai mérések, antropometriai vizsgálat, valamint a kormányoszlop állíthatóságát is szeretném biztosítani. 


\section{Köszönetnyilvánítás}

A cikkben ismertetett kutató munka az EFOP-3.6.1-16-2016-00011 jelü „Fiatalodó és Megújuló Egyetem - Innovatív Tudásváros - a Miskolci Egyetem intelligens szakosodást szolgáló intézményi fejlesztése" projekt részeként - a Széchenyi 2020 keretében - az Európai Unió támogatásával, az Európai Szociális Alap társfinanszírozásával valósul meg.

\section{Irodalom}

[1] Norton, K.M.: A Brief Histroy of Prosthetics, Amputee Coalition 2007 www.amputeecoalition.org/resources/a-brief-history-of-prosthetics/

[2] U.S. National Library of Medicine. Maimed Men. 2016 nlm.nih.gov/exhibition/lifeandlimb/maimedmen.html

[3] Witborn, T.L., Autry, D.E. WARS \& SCARS A History of the Disabled American Veterans, 2006.

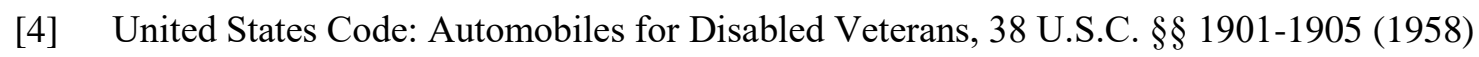

[5] Kope, D. Vechicle Steeringh Device, US 2,856,223, 1956

[6] Központi Statisztikai Hivatal: 2011. évi népszámlálás, 11. Fogyatékossággal élők, Budapest ,2014 www.ksh.hu/docs/hun/xftp/idoszaki/nepsz2011/nepsz_11_2011.pdf

[7] Disability Statistics \& Demographics: Annual Report 2017, Institute on Disability at the University of New Hampshire, 2018 https://disabilitycompendium.org/sites/default/files/useruploads/2017_AnnualReport_2017_FINAL.pdf

[8] Tom's Feet http://tomsfeet.com/

[9] Kamondi, L., Sarka, F., Takács, Á. Fejlesztés-módszertani ismeretek. Elektronikus jegyzet. Készült: „Korszerü anyag-, nano- és gépészeti technológiákhoz kapcsolódó müszaki képzési területeken kompetencia alapú, komplex digitális tananyag modulok létrehozása és on-line hozzáférésük megvalósítása" TÁMOP-4.1.2-08/1/a-2009-0001, Miskolc, 2011.

[10] Pahl, G., Beitz, W., Feldhusen, J., Grote, K.H. Engineering Design: A systematic Approach. Springer Science+Business Media, London, 2007. https://doi.org/10.1007/978-1-84628-319-2

[11] Benyó, K. Rugalmas hajtás tervezése. Oktatási segédanyag órai munkához 